\title{
Article
}

\section{Muslim identity politics: Islam, activism and equality in Britain}

\author{
Morris, Carl
}

Available at http://clok.uclan.ac.uk/28438/

Morris, Carl ORCID: 0000-0001-6698-3116 (2019) Muslim identity politics: Islam, activism and equality in Britain. Religion, State and Society . ISSN 0963-7494

It is advisable to refer to the publisher's version if you intend to cite from the work. http://dx.doi.org/10.1080/09637494.2019.1574443

For more information about UCLan's research in this area go to http://www.uclan.ac.uk/researchgroups/ and search for <name of research Group>.

For information about Research generally at UCLan please go to http://www.uclan.ac.uk/research/

All outputs in CLoK are protected by Intellectual Property Rights law, including Copyright law. Copyright, IPR and Moral Rights for the works on this site are retained by the individual authors and/or other copyright owners. Terms and conditions for use of this material are defined in the policies page.

\section{CLoK}

Central Lancashire online Knowledge www.clok.uclan.ac.uk

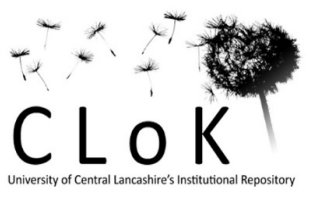




\section{Review of Elshayyal, Khadijah (2018) Muslim Identity Politics: Islam, Activism and Equality in Britain. London: I.B. Tauris.}

In recent years Britain has been shaken by a seemingly existential cultural politics - often framed as liberal/global vs conservative/nationalistic - underneath which can perhaps be found a long running failure to address, al la Paul Gilroy, the melancholia associated with a post-empire, multicultural society. Ranging from military interventionism abroad, through to racial discord at home, the reverberations of postcolonial Britain suggest a nation that is struggling to define itself for a new era. Identity politics has thrived more generally during this recent history, but Muslims in Britain have in particular been central to many of the more recent debates concerning social inclusion and pluralism: as the focus of securitisation policies, as victims of rising Islamophobia, as critics of neo-colonial adventurism, or as prominent actors within the evolving landscape of multicultural Britain. Yet despite this centrality, a lineage of Muslim voices and agencies have most often been overlooked in the political sphere.

It is within this context that Khadijah Elshayyal's historical study is located. Muslim Identity Politics: Islam, Activism, and Equality in Britain is an examination of the mobilisation of Muslim activists, as Muslims, in response to the social and political inequalities of postcolonial Britain. Drawing on key intellectual figures, such as Charles Taylor and Axel Honneth, Elshayyal develops the concept of an 'Equality Gap', suggesting that the misrecognition of Muslims in Britain has for decades required that Muslims seek to project their religious identities into the public sphere. Elshayyal proceeds over the course of Muslim Identity Politics to examine, through oral histories and official documentation, the many different ways in which this activism has manifested itself, from the 1960s through to the present day. By connecting this activism to more sweeping national narratives and debates, Elshayyal shows that Muslim activists, while sometimes overlooked, have been neither quiescent nor peripheral within the wider British political sphere.

The book is primarily a work of contemporary historical analysis. It is ordered through a social and political chronology of Muslims in Britain, from post-war settlement, through to the equality debates of the 1980s/90s and the post-9/11 concerns around military intervention, securitisation and Islamophobia. While the book re-treads familiar ground in recent political history, it does so through a focus on the role of Muslim activist organisations and networks within these wider events and debates. Muslim Identity Politics is therefore a welcome contribution to a growing collection of academic literature that is concerned with uncovering the overlooked history and heritage of Muslims in the UK.

Elshayyal begins by examining the origins of Muslim identity politics in Britain. There is an unavoidably stretched timeframe for such origins, ranging in Elshayyal's analysis from the founding of the Federation of Student Islamic Societies (FOSIS) in 1963, to the reformist groups of the 1980s, such as the influential Young Muslims UK (YMUK), through to the rise of Salafi-oriented networks in the 1990s. In making sense of this varied and sometimes disconnected set of histories, Elshayyal suggests that earlier forms of Muslim activism revolved around issues of education provision, before evolving into post-Rushdie concerns with identity and legislative lobbying. It is the diverse nature of these early pioneering groups that can make comparisons difficult at times, although common features do include the influence of wider transnational Muslim political networks, as well as the common role played by these early groups in developing different forms of Muslim leadership and organisation.

The book continues with this chronological history by examining the 'formalisation' of Muslim identity politics in the 1990s. This concerns primarily the national fallout following the Rushdie Affair and the subsequent establishment of the Muslim Council of Britain (MCB) in 1997. Elshayyal recounts a 
familiar history, concerned with debates around free speech, blasphemy and religious discrimination, before considering the political dynamics that led to the demands for a more unified representation of Muslims in Britain. More fruitfully, in this section, Elshayyal draws on the work of Tariq Modood to strengthen the central theoretical claim of the book - of an 'Equality Gap' - and to examine the specific discrimination that Muslims face as an ethno-religious group. In a direct comparison with Jews in Britain, Elshayyal suggests that Jewish organisations, such as the Board of Deputies of British Jews (BOD), have provided both a model for Muslim representation as well as a cognate for our understanding of ethno-religious discrimination.

The second half of the book is devoted almost entirely to the post-9/11 context of strained relations between British Muslims and the Government, most specifically around issues concerning terrorism, surveillance, Islamophobia and foreign policy. These concerns have been central to much of the political discourse involving Muslims in Britain and are already well documented. Consequently, the book would have benefited from more of a focus on the internal debates taking place within Muslim activist organisations, rather than what sometimes felt like a sweeping examination of recent political and legislative history. It would also have been welcome to have seen more attention given to those forms of Muslim identity politics that are thriving outside of the post-9/11 terrorism context, such as in relation to environmental activism, gender politics or business ethics.

For those overly-familiar with the field of British Muslim studies, Muslim Identity Politics will not offer content that is radically new or revealing; however, the book does do a commendable job in organising historical narratives that have been covered before but only sporadically or across a range of diverse academic sources. The book will therefore serve as an excellent overview of Muslim activism and related political history, providing a useful reference for the specialist reader, as well as an invaluable introduction to students or those from other disciplines. Overall, it is a worthy contribution to the study of contemporary British Muslim history and it adds to a growing collection of complementary academic literature in this increasingly rich and diverse field. 